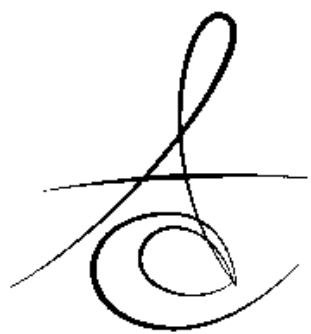

\title{
ORTHODONTIC ERUPTION AS AN ALTERNATIVE TREATMENT FOR PRIMARY TEETH INTRUSIONS: A CASE REPORT
}

\section{SÜT DİŞİ İNTRÜZYONUNDA ALTERNATİF BİR TEDAVİ OLARAK ORTODONTİK SÜRDÜRME: OLGU RAPORU}

\author{
Dr. Mehmet BANI \\ Dr. Korhan GIDDER*
}

Makale Kodu/Article code: 1764

Makale Gönderilme tarihi: 04.07.2014

Kabul Tarihi: 16.10.2014

\section{ABSTRACT}

Purpose: This case report aim describes orthodontic eruption as an alternative treatment option for the management of intruded primary tooth.

Case Report: A 5-year-old boy was referred to the Gulhane Medical Academy Centre of Dental Sciences Department, 30 minutes after he suffered a dental trauma. In intraoral examination the intrusion of the upper right primary central incisor (51) and only clinical incisal crown tip could be examined. Although 4 weeks waiting for re-eruption, teeth did not move. An orthodontic appliance was used for eruption of the intruded tooth with rubber ronder and a button on the surface of 51.

Results: Two weeks later after eruption of 51 appliance has been given-up. The patient was taken regular follow ups for 3 years. Permanent central incisors erupted normally after 3 years.

Conclusion: Orthodontic eruption may not be the first treatment choice but it can be an alternative treatment with correct indication and short time use for intruded primary teeth.

Key Words: Intrusion, orthodontic appliance, primary dentition

\section{INTRODUCTION}

Trauma to oral and facial structures is a significant problem that may have serious medical, esthetic and psychological consequences on both children and their parents ${ }^{1-3}$. Children are prone to trauma because of incomplete physical and cognitive development ${ }^{4,5}$. Studies have shown that approximately $30 \%$ of all children under the age of 7

\section{ÖZET}

Amaç: Bu olgu sunumu amacı süt dişi intrüzyonu için alternatif bir tedavi seçeneği olarak ortodontik sürdürme anlatmaktır.

Olgu Raporu: 5 yaşındaki erkek çocuk Gülhane Tıp Akademisi Merkezi Diş Hekimliği Bölümü'ne diş travması şikayeti ile travmadan 30 dakika sonra başvurdu. Ağız içi muayenesinde, sağ üst süt orta kesici dişte (51) sadece insizal kronu görülen bir intrüzyon bulunmaktaydı. Geri sürmesi için 4 hafta beklendi ancak dişte hareket olmadı. Ortodontik aparey, 51 nolu dişin bukkal yüzeyinde bir metal buton ve lastik kullanılarak intrüze dişin sürdürülmesi için kullanıldı.

Bulgular: İki hafta sonra sonra 51'in sürmesi ile aparey kullanımı bırakıldı. Hasta 3 yı boyunca düzenli kontrolleri yapıldı. Hasta 3 yıl takibi sonunda daimi santral kesici dişin normal sürdüğü görüldü.

Sonuç: Süt dişi intrüzyonlarında otodontik sürdürme ilk tercih edilen tedavi seçeneği olmayabilir ancak doğru endikasyon ve kısa süre kullanımı ile alternatif bir tedavi olabilir

Anahtar Kelimeler: İntrüzyon, ortodontik aparey, süt dişlenme

experience injuries to one or more of their primary incisors ${ }^{6,7}$.

Intrusive luxation is one of the most severe type of trauma in children ${ }^{8-10}$. Intrusive luxations constitute $4.4 \%-22 \%$ of traumatic injuries in primary dentition ${ }^{4}$. Because of their exposed position in the dental arch, the maxillary central incisors are affected by traumatic injury at significantly higher rates than other teeth ${ }^{11,12}$. An intrusive injury is caused by a force in an axial direction that results in displacement

- Gazi University, Faculty of Dentistry, Department of Pediatric Dentistry

" Gülhane Medical Academy, Center of Dental Sciences, Department of Orthodontics 
of the tooth within its socket ${ }^{2,8,13}$. Sometimes it will be completely intruded into the alveolar bone, mistakenly assumed to be lost and incisal part may remain visible with clinical crown shorter than adjacent nontraumatized tooth ${ }^{14-18}$.

Primary tooth intrusion may result in a variety of pathological alterations to permanent teeth, including hypoplasia; crown dilaceration; root angulation or dilaceration; partial or complete arrest of root formation; sequestration of the permanent tooth germ; and disturbances in eruption ${ }^{19}$. Depending on the severity of the intrusion, the American Academy of Pediatric Dentistry recommends either extraction or spontaneous re-eruption for the primary tooth ${ }^{20}$. In most cases, treatment of complicated injuries in primary dentition has been limited to extraction of the affected tooth ${ }^{13,21}$. There is no agreement on the ideal treatment of primary intruded teeth after trauma ${ }^{13}$. This case report provides a brief insight into orthodontic eruption as an alternative treatment option for the management of intruded primary tooth in a 5 -year-old boy.

\section{CASE REPORT}

A 5-year-old boy was referred to the Gulhane Medical Academy Centre of Dental Sciences Department of Emergency Clinic, 30 minutes after he suffered a dental trauma. The child was in good general health and had no neurologic problems. The child's parents reported that he had fallen at the home.

The intrusion of the upper right deciduous central incisor (51) and only clinical incisal crown tip could be examined in Intraoral examination (Fig 1). On palpation, a hardened surface was observed in the buccal area. Radiographic examination showed deviation in which the buccal 51 intrusion tooth and no problem with the position permanent tooth and no alveolar bone fractured (Fig 2). If Intruded primary teeth root displaced buccal displacement of the root recommends re-eruption spontaneously. Re-eruption generally begins within 2-3 weeks. Re-eruption was waited for 4 weeks but 51 did not move.

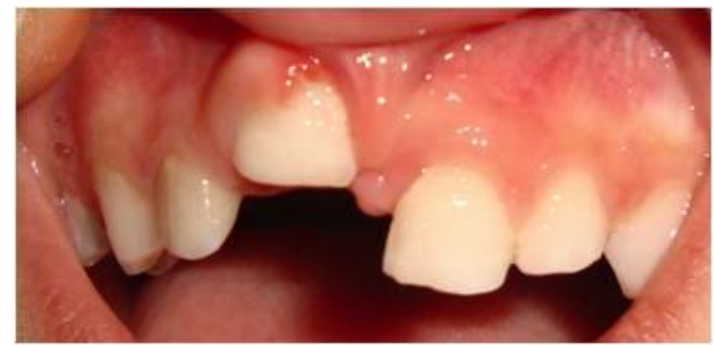

Figure 1. Right maxillary primary incisor view intrusion

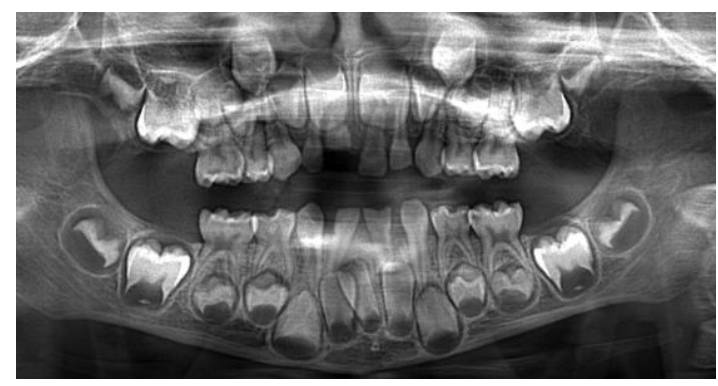

Figure 2. Panoramic radiograph showing intruded tooth

Intruted teeth was planned to erupt by an orthodontic appliance (Fig 3). The orthodontic treatment objective were to provide an alternative treatment option for the management of intruded primary tooth. Thus, a button bonded to the buccal surface of 51 was attached to the appliance with an elastic rondel for eruption. Two weeks later after eruption of 51 appliance has been given-up (Fig 4a,b). The patient was rescheduled regular follow-up every 6 months for 3 years and clinical and radiologic examinations showed no alterations. As soon as permanent central incisor began to erupt 51 was extracted in 7 year old patient (Fig 5). 3 years followup showed that permanent central incisors erupted in 8 year old patient (Fig 6).

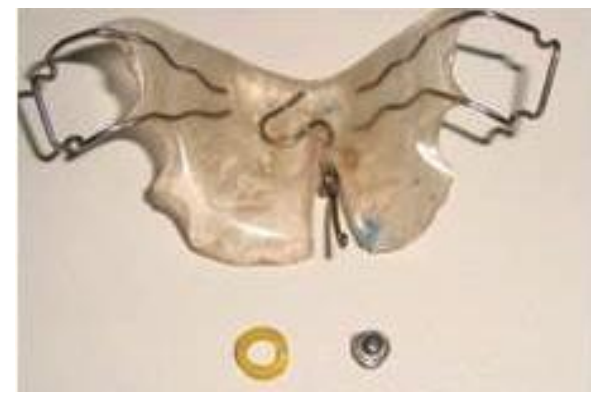

Figure 3. View of orthodontic appliance 


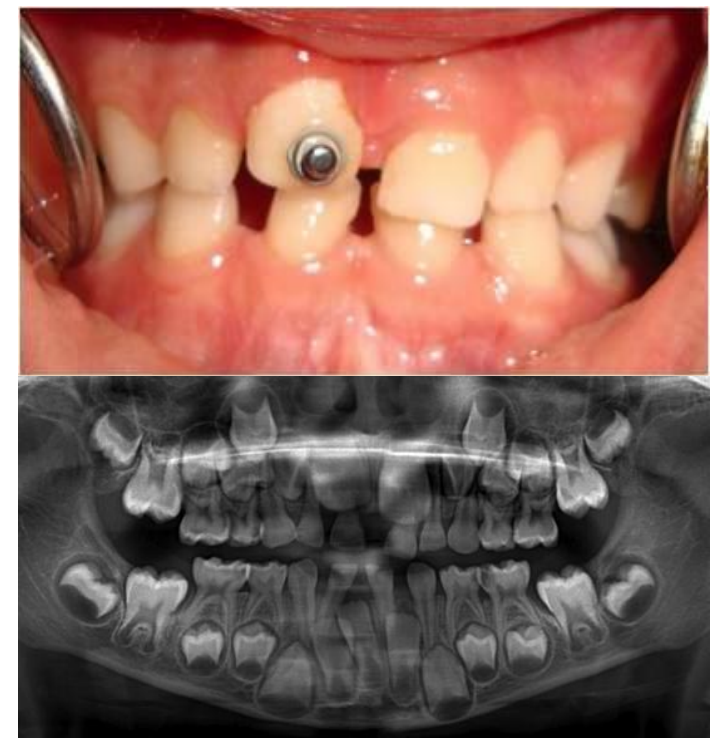

Figure 4. Clinical and radiographic views, two weeks after orthodontic appliance

a) clinical examination revealed normal mucosa and no discoloration of the dental crown;

b) radiographic examination showed normal characteristics

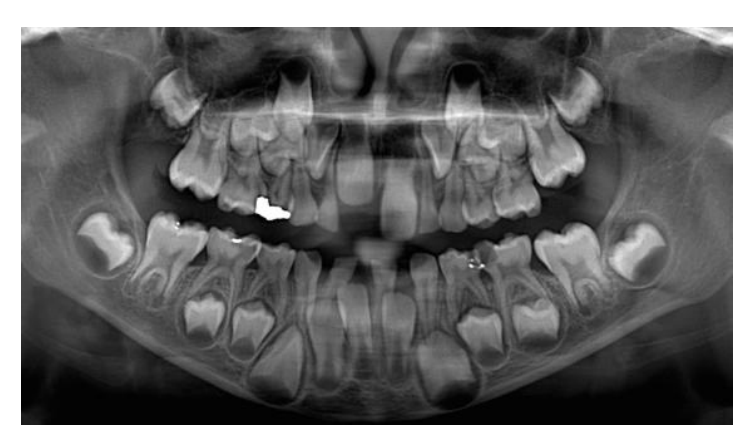

Figure 5 . View of panoramic radiography after primary central incisor extraction

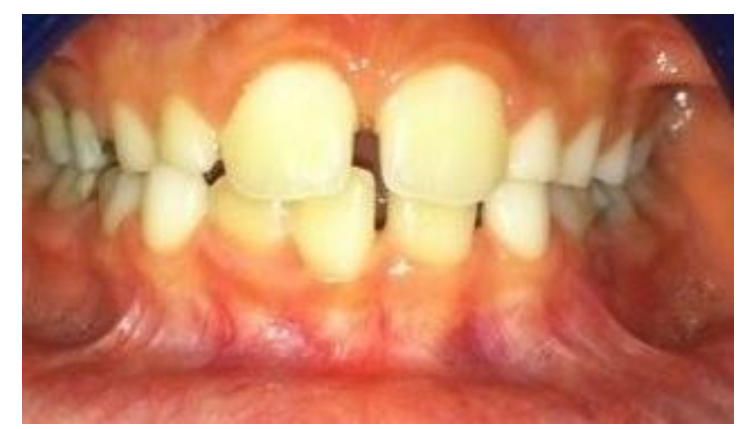

Figure 6. Intraoral view after permanent central incisor eruption

\section{DISCUSSION}

Treatment of intrusive injuries in primary dentition includes determination of the relationship between the primary and the permanent teeth ${ }^{13}$. The root of the primary incisor is normally on close proximity with buccal surface ot the permanent teeth. Root of the primary teeth is pushed against the crown permanent teeth, it may severely damaged ${ }^{8,14,17}$. Fortunately, the root apex of maxillary primary iscisors has a buccal curvature leading the root away from the permanent teeth in more than \%80 of case $^{15}$. If intruded primary teeth root displaced palatally immediate extraction is recommended, but buccal displacement of the root recommends reeruption spontaneously $8,13,18$. Re-eruption generally begins within 2-3 weeks. If re-eruption fails, ankylosis should be suspected. Ankylose tooth can disorder eruption of the permanent teeth ${ }^{8}$.

In this case report root of intruted teeth had buccal location, no hemorrage and swelling, proper alingment of the permanent successor as seen on radiograph, intruted teeth not opaque image. Therefore, re-eruption expected 4 weeks but there were no movement of 51 . There was the risk of tooth ankylosis, so orthodontic appliance was immediately thought to use for eruption. The patient was asked to use the appliance with an elastic rondel from the button bonded to the buccal surface of 51 and change the rondels daily. After two weeks with the eruption of 51 appliance use was given up. The patient was rescheduled regular follow-up every 6 months for 3 years. Clinical examination revealed no discoloration of the dental crown or pain, and the mucosa presented normal characteristics. Radiographic examination showed no alterations. As soon as permanent central incisor began to erupt 51 was extracted in 7 year old patient.

However orthodontic treatment is a rituel for intrusions of permanent teeth, it is not preferred for primary teeth intrusions. In this case report we had successful response with orthodontic appliance in a short time such as two weeks. During 3 years followup no pathological symptoms observed in 51 and permanent central incisors erupted normally. 


\section{CONCLUSION}

Extraction or waiting for re-eruption are general treatment procedures in primary teeth intrusions. But, orthodontic eruption can be an alternative treatment with correct diagnosis. Although successful responses were observed to orthodontic treatment in this case report, in primary teeth intrusions it is suggested to use the appliance with correct indication and for a short time.

\section{REFERENCES}

1. Rocha MJ, Cardoso M. Survival analysis of endodontically treated traumatized primary teeth. Dent Traumatol 2007;23:340-7.

2. Andreasen JO, Andreasen FM, Andersson L. Textbook and color atlas of traumatic Injuries to the Teeth. 4th ed. Copenhagen: Blackwell Munksgaard; 2007.

3. Unal M, Tuğut F, Demir H. Three years follow up of traumatic complicated crown fracture and lateral luxation treatment: case report. J Dent Fac Atatürk Uni 2013;13:380-4.

4. Canoglu E, Akcan CA, Baharoglu E, Gungor HC, Cehreli ZC. Unusual ectopic eruption of a permanent central incisor following an intrusion injury to the primary tooth. J Can Dent Assoc 2008;74:723-6.

5. Harrington MS, Eberhart AB, Knapp JF. Dentofacial trauma in children. ASDC J Dent Child 1988;55:334-8.

6. Borum MK, Andreasen JO. Sequelae of trauma to primary maxillary incisors. I. Complications in the primary dentition. Endod Dent Traumatol 1998;14:31-44.

7. Orders ML, Koch G. Developmental disturbances in permanent successors after injuries to maxillary primary incisors. Eur J Pediatr Dent 2001;2:16572.

8. Koch G, Poulsen S. Pediatric dentistry a clinical approach. 2nd ed. Wiley-Blackwell; 2009.

9. Gondim JO, Moreira Neto JJ. Evaluation of intruded primary incisors. Dent Traumatol 2005;21:131-3.

10. Kargul B, Çağlar E, Tanboğa I. Dental trauma in Turkish children, Istanbul. Dent Traumatol 2003;19:72-5.

11. Andreasen JO, Ravn JJ. Epidemiology of traumatic dental injuries to primary and permanent teeth in a
Danish population sample. Int J Oral Surgery 1972;1:235-9.

12. Galea H. An investigation of dental injuries treated in an acute general hospital. J Am Dent Assoc 1984;109:434-8.

13. Gomes AC, Messias LPDA, Delbem ACB, Cunha RF. Developmental disturbance of an unerupted permanent incisor due to trauma to its predecessor. J Can Dent Assoc 2010;76:a57.

14. Pinkham JR, Casamassimo PS, McTigue DJ, Fields HW, Nowak AJ. Pediatric dentistry: Infancy through adolescence. 4th ed. Elsevier Saunders; 2005.

15. Holan G, Ram D. Sequelae and prognosis of intruded primary incisors: a retrospective study. Pediatr Dent 1999;21:242-7.

16. Flores MT. Traumatic injuries in the primary dentition. Dent Traumatol 2002;18:287-98.

17. Carvalho V, Jacomo DR, Campos V. Frequency of intrusive luxation in deciduous teeth and its effects. Dent Traumatol 2010;26:304-7.

18. Odersjö ML, Koch G. Developmental disturbances in permanent successors after injuries to maxillary primary incisors. Eur J Pediatr Dent 2001;2:16572.

19. Diab M, el Badrawy HE. Intrusion injuries of primary incisors. Part III: effects on the permanent successors. Quintessence Int 2000;31:377-84.

20. Shanmugam HV, Arangannal P, Vishnurekha C, Nichani MH, Vijayaprabha K. Management of intrusive luxation in the primary dentition by surgical repositioning: an alternative approach. Aust Dent J 2011;56:207-11.

21. Kahabuka FK, Willemsen W, van't Hof M, Ntabaye MK, Burgersdijk R, Frankenmolen $F$, et al. Initial treatment of traumatic dental injuries by dental practitioners. Endod Dent Traumatol 1998;14:2069.

\author{
Yazışma Adresi \\ Dr. Mehmet Bani \\ Gazi University, Faculty of Dentistry, \\ Department of Pediatric Dentistry, 06510, \\ Emek, Ankara, Turkey \\ Tlf:+903122034088 \\ Fax:+903122239226 \\ e-mail: mehmetbani@hotmail.com
}

